\title{
Abundance, Activity and Community Structure of Denitrifiers in Drainage Ditches in Relation to Sediment Characteristics, Vegetation and Land-Use
}

\author{
Annelies J. Veraart, ${ }^{1,2 *}$ Maurício R. Dimitrov ${ }^{1,3}$ Arina P. Schrier-Uijl, ${ }^{4}$ \\ Hauke Smidt, ${ }^{3}$ and Jeroen J. M. de Klein ${ }^{2}$
}

\begin{abstract}
${ }^{1}$ Department Microbial Ecology, Netherlands Institute of Ecology, Wageningen, The Netherlands; ${ }^{2}$ Aquatic Ecology and Water Quality Management Group, Wageningen University, Wageningen, The Netherlands; ${ }^{3}$ Laboratory of Microbiology, Wageningen University, Wageningen, The Netherlands; ${ }^{4}$ Nature Conservation and Plant Ecology Group, Wageningen University, Wageningen,
\end{abstract} The Netherlands

\begin{abstract}
Drainage ditches are ubiquitous yet understudied features of the agricultural landscape. Nitrogen pollution disrupts the nutrient balance of drainage ditch ecosystems, as well as the waterbodies in which they drain. Denitrification can help ameliorate the impact of $\mathrm{N}$-fertilization by converting reactive nitrogen into dinitrogen gas. However, factors affecting denitrification in drainage ditches are still poorly understood. In this study, we tested how within-ditch and regional environmental conditions affect denitrifier activity, abundance, and community structure, to understand controls on denitrification at multiple scales. To this end, we quantified in situ denitrification rates and
\end{abstract}

Received 14 July 2016; accepted 13 September 2016;

published online 23 November 2016

Electronic supplementary material: The online version of this article (doi:10.1007/s10021-016-0083-y) contains supplementary material, which is available to authorized users.

Author Contributions Conceived of and designed study: Annelies J. Veraart, Arina P. Schrier-Uijl, Jeroen J. M. de Klein. Performed Research: Annelies J. Veraart, Mauricio R. Dimitrov, Arina P. Schrier-Uijl. Analysed data: Annelies J. Veraart, Mauricio R. Dimitrov. Contributed new methods: Mauricio R. Dimitrov, Hauke Smidt. Wrote the paper: Annelies J. Veraart with the help from all authors.

Data Archiving Data deposited in the Marine Data Archive (MDA), http://www.vliz.be/en/marine-data-archive.

*Corresponding author; e-mail: A.veraart@nioo.knaw.nl denitrifier abundance in 13 drainage ditches characterized by different types of sediment, vegetation and land-use. We determined how denitrification rates relate to denitrifier abundance and community structure, using the presence of nirS, nirK and nosZ genes as a proxy. Denitrification rates varied widely between the ditches, ranging from 0.006 to $24 \mathrm{mmol} \mathrm{N} \mathrm{m}^{-2} \mathrm{~h}^{-1}$. Ditches covered by duckweed, which contained high nitrate concentrations and had fine, sandy sediments, were denitrification hotspots. We found highest rates in ditches next to arable land, followed by those in grasslands; lowest rates were observed in peatlands and nature reserves. Denitrification correlated to nitrate concentrations, but not to nirK, nirS and nosZ abundance, whereas denitrifier-gene abundance correlated to organic matter content of the sediment, but not to nitrate concentrations. Our results show a mismatch in denitrification regulators at its different organizational scales. Denitrifier abundance is mostly regulated at within-ditch scales, whereas $\mathrm{N}$-loads, regulated by landscape factors, are most important determinants of instantaneous denitrification rates.

Key words: agroecosystem; denitrification; DGGE; ecosystem functioning; nitrogen; macrophytes; qPCR; wetlands. 


\section{INTRODUCTION}

Drainage ditches are man-made ecosystems, designed to regulate water levels in low-lying agricultural areas and reclaimed wetlands (Painter 1999; Herzon and Helenius 2008; Zhang and others 2016). In the Netherlands, they comprise a total length of $300,000 \mathrm{~km}$ (Peeters and others 2014). Besides their importance for drainage of agricultural fields and natural areas, they form a unique ecosystem type, consisting of numerous networks of shallow, lowgradient waterbodies, with low flow velocities. Typical features of the agricultural drainage ditch ecosystem are high nutrient loads and tight aquaticterrestrial coupling, which makes them more similar to (constructed) wetlands than to streams, as which they are often classified. Ditches often receive runoff and nitrogen-rich groundwater from adjacent fields, leading to excessive production of macrophytes and macroalgae, floating plant dominance, and consequently hypoxia and biodiversity loss (Janse and Van Puijenbroek 1998; Scheffer and others 2003; van Gerven and others 2015). Nitrogen loads from ditches contribute to eutrophication in connected waters, such as canals, lakes and reservoirs (Needelman and others 2007). This can be partly counteracted by denitrification (de Klein and Koelmans 2011 ; Kröger and others 2014), a major Nremoving process that reduces nitrate to gaseous nitrogen.

Denitrification is performed by microorganisms and requires an electron donor like easily degradable organic carbon, and nitrate as terminal electron acceptor (Knowles 1982). In freshwater sediments, denitrification usually takes place in anoxic-oxic boundary layers, where nitrate is supplied from the oxic zone (Seitzinger and others 2006). Similar to wetlands, agricultural ditches are potential denitrification hotspots, due to their tight terrestrial-aquatic coupling, high nitrate inputs, suitable redox conditions, ample anoxic-oxic interface and sediments rich in organic matter (McClain and others 2003; Veraart and others 201la). However, denitrification rates in ditches have been found to vary widely (de Klein and Koelmans 2011), and it remains unclear which factors are most important in regulating denitrification in these ecosystems.

Factors affecting denitrification act at two different levels: they drive not only the abundance and diversity of the denitrifying microorganisms present, but also the amount of nitrate converted by the resultant denitrifying community (Wallenstein and others 2006). Although most denitrifiers present in the environment remain uncharacterized (Philippot and Hallin 2005), abundance of genes coding for denitrification enzymes can be used to probe denitrification potential $\left(\mathrm{O}^{\prime}\right.$ Connor and others 2006; Graham and others 2010), whereas variation within functional genes may be used as indicator of denitrifier diversity (Hallin and Lindgren 1999; Throbäck 2006).

In this study, we determine how denitrification rates in drainage ditches relate to denitrifier abundance and community structure, using the presence of genes coding for nitrite reductase (nirS, nirK) and nitrous oxide reductase enzymes (nosZ clade I, hereafter: nos $Z_{I}$ ) as a proxy. Furthermore, we test how in turn denitrifier activity, abundance and community structure are affected by their environment, at both within-ditch and landscape scales. To this end, we quantify denitrification rates and denitrifier abundance in drainage ditches characterized by different types of sediments, vegetations and land-uses, using an in situ isotope labelling technique, and APCR and DGGE of the denitrifying community. This way, we can capture controls on denitrification in drainage ditches at organizational scales from microbes to ecosystems.

\section{METHODS}

\section{Study Sites and Sampling Design}

We sampled 13 drainage ditches (Table 1; Figure 1); all ditches were straight (non-meandering), shallow (max depth $80 \mathrm{~cm}$ ) and between 1.2 and $6 \mathrm{~m}$ wide. They were all situated in a flat landscape, resulting in standing water or negligible flow velocities, regulated by pumping stations. Seven of these ditches were located in peat areas, and were also used to quantify the ditches' greenhouse gas emission (Pl-P4 and SP1-SP3, (Schrier-Uijl and others 2011). We selected the other six ditches to include clay sediments (C1-C4) and fine, sandy sediments (FS1, FS2), the latter of which the top layer consisted of fine, decomposed, material. The ditches were situated in agricultural areas (crops or meadows) and nature reserves or protected areas (mostly peatlands), and therefore differed in yearly $\mathrm{N}$-loads (Table 1). Each ditch was sampled once, in early summer of the same year. We measured denitrification rates, dissolved oxygen, temperature, dissolved organic carbon (DOC), $\mathrm{NO}_{3}{ }^{-}, \mathrm{NH}_{4}{ }^{+}$, electric conductivity (EC) and $\mathrm{pH}$ in the water column, and the organic matter content (OM\%) and oxygen demand of the sediment (SOD). Additionally, the structure and abundance of the nirK, nirS and nos $Z_{I}$ gene pools in the top layer of 


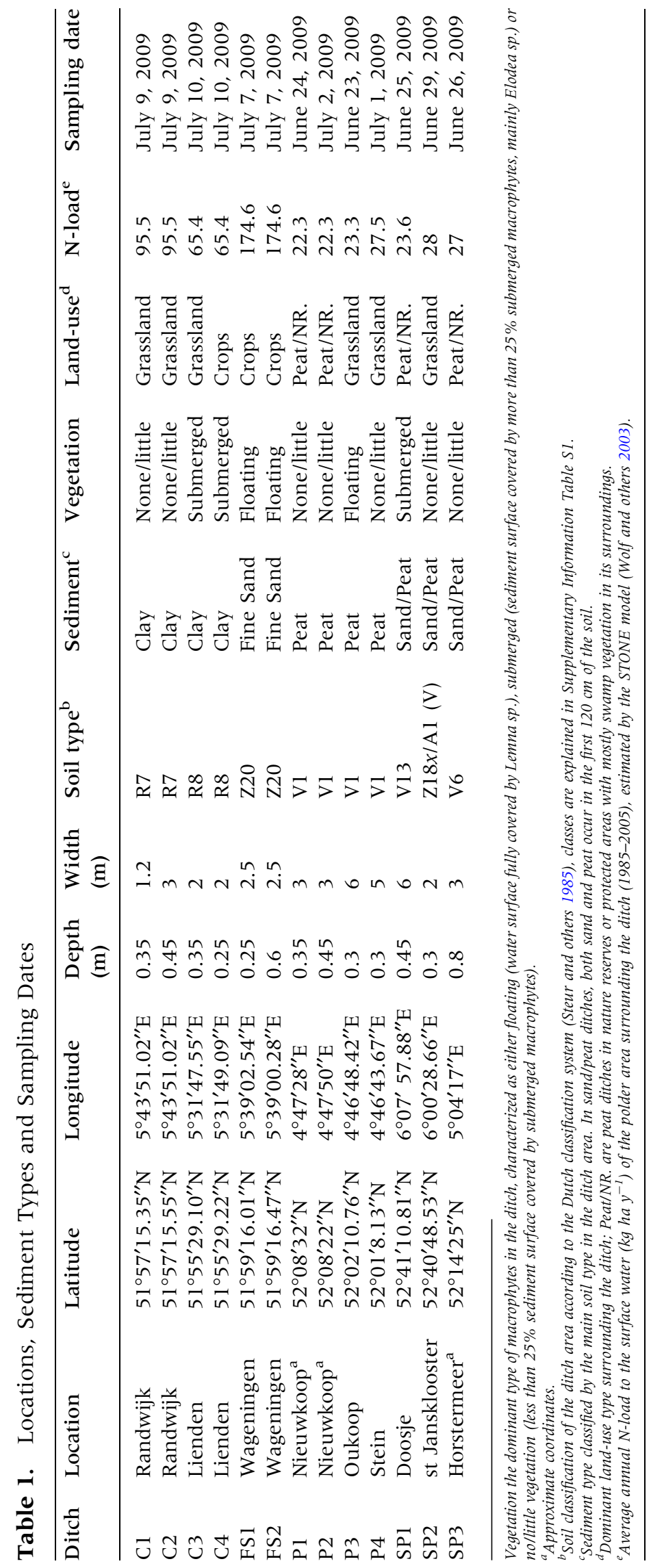



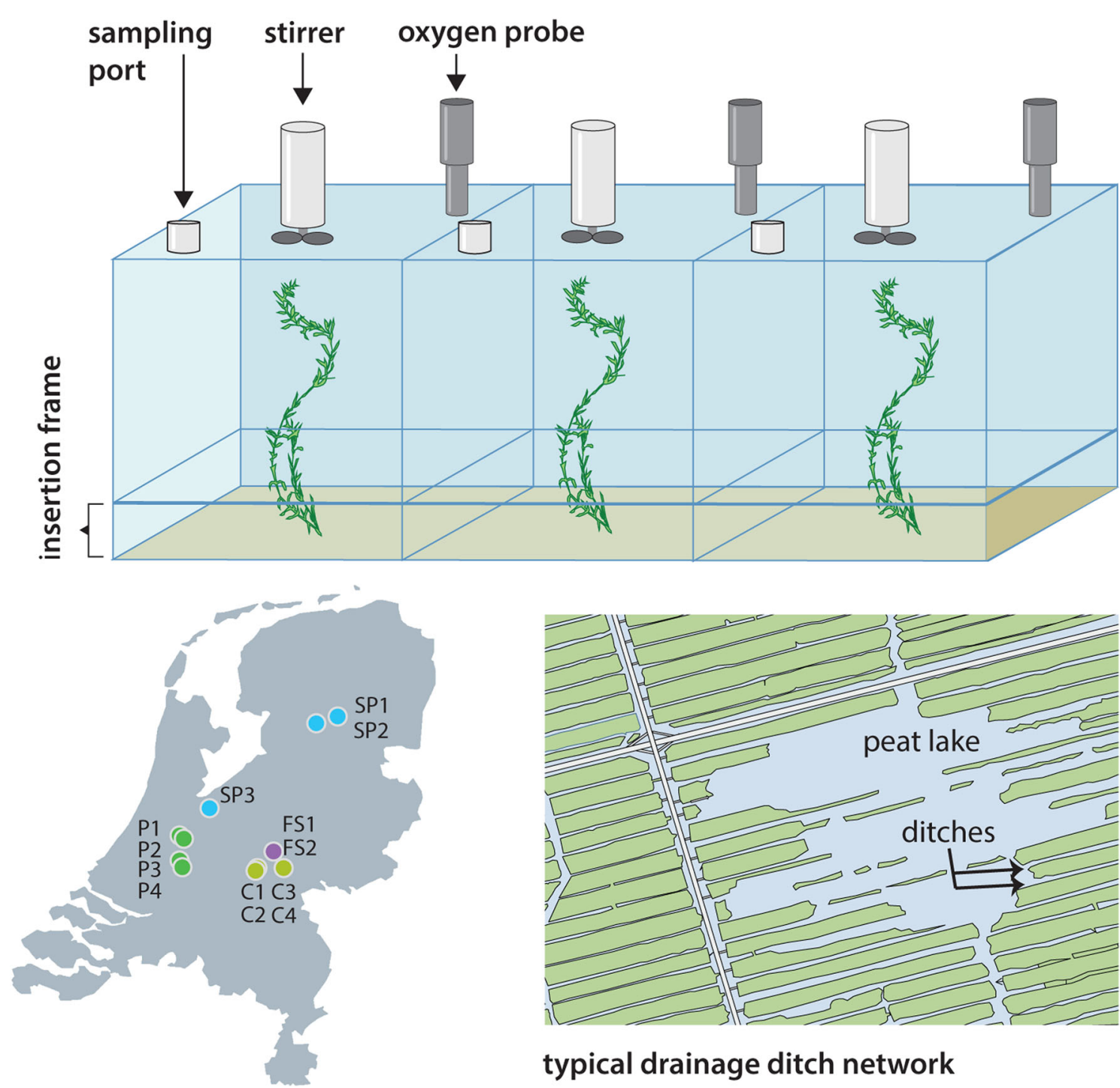

\section{typical drainage ditch network}

Figure 1. Overview of sampling locations and denitrification-chamber design. Upper panel shows the split-box chamber used for in situ denitrification measurements. Lower panel shows sampling locations and an example of a drainage ditch network in peat areas.

the sediment were analysed. Furthermore, we determined dominant macrophyte structures by estimating the coverage of floating and submerged vegetation in each ditch.

\section{Denitrification Measurements}

Denitrification rates were measured in situ using the ${ }^{15} \mathrm{~N}$ isotope-pairing technique in split-box benthic measuring chambers (Figure 1). Use of benthic chambers allows study of denitrification rates under field conditions, and was found to give similar results as more labour intensive laboratory batch-mode assays (Nielsen and Glud 1996; Mengis and others 1997). Measuring under in situ conditions better reflects actual denitrification rates than laboratory incubations. The addition of ${ }^{15} \mathrm{~N}$-labelled substrate enables denitrification measurements at relatively low $\mathrm{NO}_{3}{ }^{-}$concentrations, which reduces overestimation of denitrification. The perspex splitbox chambers consisted of a frame and three parallel chambers (12 l each). One split-box chamber was installed in each ditch. We placed the frames in the sediment at least $\mathrm{l} \mathrm{h}$ before starting the measurements. After settling of the disturbed sediment, we placed the three parallel chambers on the frame, fully submersed in the ditch water, capturing submerged vegetation, when present. The top 
of the chamber contained a screw cap opening with a septum, through which ${ }^{15} \mathrm{~N}$ could be injected and water samples could be taken. We placed a stirrer next to the septum opening in the chamber, to gently mix the ${ }^{15} \mathrm{~N}$ through the chamber water, and to optimize diffusion of ${ }^{15} \mathrm{~N}$ into the sediment. Measurements were performed in the morning, and each day one ditch was sampled. We injected $5 \mathrm{ml} 0.16 \mathrm{M}{ }^{15} \mathrm{~N}\left[\mathrm{NaNO}_{3}\right]$ through the septum of each chamber, to enrich the water in each chamber with $1 \mathrm{mg} \mathrm{l}^{-1}{ }^{15} \mathrm{~N}$. Water samples for $\mathrm{N}_{2}$ analysis were taken with an airtight glass syringe, whereupon $5 \mathrm{ml}$ of sample was transferred into a helium flushed pre-evacuated 12-ml exetainer (Labco Wycombe), which contained $100 \mu \mathrm{l}(50 \% \mathrm{w}: \mathrm{v})$ $\mathrm{ZnCl}_{2}$, to stop microbial activity. Water samples (triplicates) were taken $0.25,1,2$, and $3 \mathrm{~h}$ after injecting the ${ }^{15} \mathrm{~N}$ solution. Samples were stored at room temperature until the end of analysis. Before analysis, samples were vigorously shaken to transfer the dissolved $\mathrm{N}_{2}$ into the helium headspace. Denitrification rates were calculated from the increase of ${ }^{29} \mathrm{~N}_{2}$ and ${ }^{30} \mathrm{~N}_{2}$ in the headspace (Nielsen 1992; Steingruber and others 2001), measured at a SerCon Cryoprep trace gas concentration system interfaced to a PDZ Europa 20-20 isotope ratio mass spectrometer (Sercon Ltd., Cheshire, UK). $\mathrm{N}_{2} \mathrm{O}$ emission was measured in seven of the sampled ditches, and was found to be negligible (Schrier-Uijl and others 2011).

\section{Conditions in the Water Column}

Dissolved oxygen, temperature $(\mathrm{T})$, electric conductivity (EC), and $\mathrm{pH}$ in the ditches were measured using an HQ multiprobe with a luminescent dissolved oxygen sensor (Hach Company, Loveland, Colorado, USA), at a location undisturbed by placing the denitrification chambers. We measured depth profiles at $10-\mathrm{cm}$ intervals for $\mathrm{O}_{2}$ and T. EC and $\mathrm{pH}$ were measured at $20-\mathrm{cm}$ depth in the water column.

For nutrient analysis, mixed water column samples were collected within $2 \mathrm{~m}$ from the denitrification chambers. Samples were filtered in the field using $0.45 \mu \mathrm{m}$ cellulose nitrate filters (Whatman ltd., Kent, UK), kept cool on ice during transportation and stored at $-20^{\circ} \mathrm{C}$ upon arrival in the laboratory. Nutrient concentrations $\left(\mathrm{NO}_{3}{ }^{-}+\mathrm{NO}_{2}{ }^{-}, \mathrm{NH}_{4}{ }^{+}\right.$, ortho- $\left.\mathrm{PO}_{4}{ }^{3-}\right)$ were measured colorimetrically using a SAN ${ }^{\text {plus }}$ autoanalyzer (Skalar Analytical, Breda, the Netherlands) as described by Veraart and others (201la) and references therein. DOC was measured using a Total Organic Carbon Analyser (Model 700, O.I. Inter- national, College Station, TX, USA). Estimates of groundwater seepage in the ditch area were obtained from hydrological maps (van der Gaast and others 2006).

\section{Sediment Characteristics}

The top $3 \mathrm{~cm}$ of the sediment was sampled using a Kajak corer at 3 locations within $1 \mathrm{~m}$ of the denitrification chambers. Samples were mixed to create one mixed sediment sample per ditch, kept on ice during transportation and frozen at $-20^{\circ} \mathrm{C}$ until analysis. Organic matter content was determined from the loss on ignition at $550^{\circ} \mathrm{C}$ for $3 \mathrm{~h}$. Sediment oxygen demand was measured in the field, by inserting a closed dark chamber $(10 \mathrm{~cm}$ high, $10 \mathrm{~cm}$ wide) in bare sediment and monitoring oxygen decrease in the static water at 5-min intervals for at least $3 \mathrm{~h}$ using a luminescent dissolved oxygen sensor (Hach Company, Loveland, Colorado, USA).

\section{nirK, nirS and nosZ $Z_{\text {I }}$ Community Structure}

Diversity of the nirK, nirS and nos $Z_{I}$ genes encoding for nitrite-reductase and nitrous oxide reductase, key enzymes in denitrification, were used as a proxy of the denitrifier community structure. These genes were chosen because they code for those enzymes that produce the gaseous intermediates and products of denitrification, and thus mediate $\mathrm{N}$-removal. Sediment samples from the top $3 \mathrm{~cm}$ of sediment were collected and stored as described above. Total DNA was extracted from each sediment sample using a FastDNA ${ }^{\circledR}$ SPIN Kit for Soil (MP Biomedicals, Irvine, CA, USA), according to the manufacturers' protocol. After extraction, DNA templates were purified using a OneStep ${ }^{\mathrm{TM}}$ PCR Inhibitor Removal Kit (Zymo Research, Orange, CA, USA). DNA quality and quantity were checked using a Nanodrop ND-100 spectrophotometer (Thermo Scientific, San Jose, CA, USA) and 1\% $(\mathrm{w} / \mathrm{v})$ agarose gel electrophoresis, after which the DNA templates were diluted to 20 ng DNA $\mu \mathrm{I}^{-1}$.

Gene fragments were amplified with the primers $\mathrm{FlaCu}$ and $\mathrm{R} 3 \mathrm{Cu}$ for nirK (Hallin and Lindgren 1999), Cd3aF and R3 cd for nirs (Michotey and others 2000; Throbäck and others 2006), and nosZF and nosZ622R for nos $Z_{I}$ (Kloos and others 2001; Enwall and others 2005), with reverse primers having a 33-bp GC-clamp attached to the 5'end. PCR amplification was performed in a total reaction volume of $50 \mu \mathrm{l}$, containing $10 \mu \mathrm{l}$ of $5 \times$ Green GoTaq Reaction Buffer (Promega), $200 \mu \mathrm{M}$ of each 
dNTP, $0.4 \mu \mathrm{M}$ of each primer, 1.25 U of GoTaq DNA polymerase (Promega) and $2 \mu \mathrm{l}$ (40 ng) of DNA. Bovine Serum Albumin (BSA) was added to a final concentration of $200 \mathrm{ng} \mathrm{ll}^{-1}$ to improve PCR performance. PCR protocols are described in Veraart and others (2014). PCR amplicons were analysed by $1 \%(\mathrm{w} / \mathrm{v})$ agarose gel electrophoresis and visualized under UV light after SYBRSafe (Invitrogen) staining.

Denaturing Gradient Gel Electrophoresis (DGGE) analysis of amplicons was performed as described by Muyzer and Smalla (1998), using a Dcode Universal Mutation Detection System (Bio-Rad, Hercules, CA, USA). DGGE was performed on $8 \%$ polyacrylamide gels with a denaturant gradient from 40 to $70 \%$ ( $100 \%$ denaturing acrylamide was defined as $7 \mathrm{M}$ urea and $40 \%$ (v/v) formamide). Aliquots of PCR products were loaded on the gel, and electrophoresis was carried out with $0.5 \%$ Tris acetic acid EDTA buffer at $60^{\circ} \mathrm{C}$ and at $85 \mathrm{~V}$ for $16 \mathrm{~h}$, initiated by a pre-run of $10 \mathrm{~min}$ at $120 \mathrm{~V}$. After electrophoresis, gels were silver-stained (Sanguinetti and others 1994) and scanned using a GS800 Calibrated Densitometer (Bio-Rad Hercules, CA, USA).

\section{Quantitative PCR}

Abundance of the nirK, nirs and nos $Z_{I}$ genes was determined using quantitative PCR. DNA was isolated and purified as described above. Fragments of the genes were amplified using primers nirK876 and nirK1040 for nirK (Henry and others 2004b), nirSCd3aF and nirSR3 cd for nirs (Kandeler and others 2006) and nosZ2F and nosZ2R for nos $Z_{I}$ (Henry and others 2006). The $25 \mu$ final volume reaction contained $12.5 \mu \mathrm{l} \quad \mathrm{iQ}^{\mathrm{TM}} \mathrm{SYBR}^{\circledR}$ Green supermix (BioRad Hercules, CA, USA), $1.4 \mu \mathrm{M}$ of each primer, $0.25 \mu \mathrm{l}$ BSA (final concentration $200 \mathrm{ng}$ BSA $\mu \mathrm{l}^{-1}$ ), and $5 \mu \mathrm{l}$ (corresponding to $10 \mathrm{ng}$ ) of sample DNA. Thermal cycling was performed using a BioRad CFX96 real-time thermal cycler (Bio-Rad, Hercules, CA, USA), as described in Veraart and others (2014). Specificity of fragment amplification was checked by observing a single band of expected size in a $1.5 \%$ agarose gel, and the presence of a single melting peak on the melting curve.

\section{Data analysis and Bionumerics}

DGGE band detection was performed using Bionumerics software (version 4.61 Applied Maths, Belgium), with an optimum of $0.5 \%$ and a $0.5 \%$ position tolerance, but with manual adjustment to avoid misplacing of bands. A reference marker, included on the gel in three different positions, was used as standard for normalization, ensuring sample-to-sample comparability. Similarity between DGGE profiles was determined by calculating similarity indices using the Dice similarity coefficient, which takes into account the presence or absence of specific bands. The unweighted pair-group method with arithmetic means (UPGMA) algorithm was used for dendrogram construction. Richness of the nirK, nirs and nos $Z_{I}$ gene pools was obtained from the number of visible bands, which represent operational taxonomic units (OTUs). This method cannot capture the complete richness and diversity existing in these gene pools, but will only depict the most abundant species targeted by the primers used. Nonetheless, comparing DGGE-based richness values can point at potential richness effects at the community level.

We tested for differences in denitrification rates between sediment types and vegetation types using one-way ANOVA. Relations between denitrification and potential explaining variables were tested by linear regression analysis. If necessary, data were $\ln (x+1)$ transformed to achieve a normal distribution. We used redundancy analysis (RDA) to test how environmental variables explained variation in nirK, nirs and nos $Z_{I}$ OTUs. The absence/ presence for each of the observed OTUs was entered as species data in the ordination. Nitrate, $\mathrm{NH}_{4}-\mathrm{N}, \mathrm{PO}_{4}-\mathrm{P}, \mathrm{DOC}, \mathrm{O}_{2}, \mathrm{~T}, \mathrm{EC}$ and sediment organic matter \% were $\ln (x+1)$ transformed and entered as environmental data. Scaling was focused on inter-sample distances. Significance of the canonical axes was evaluated by Monte-Carlo permutation tests (499 permutations). Statistical analyses were performed in SPSS 23 (IBM SPSS statistics, Armonk, NY, USA) and CANOCO 5.03 (Ter Braak and Smilauer, Biometris, Wageningen, the Netherlands).

\section{Results}

\section{Conditions in the Ditches}

The sampled ditches varied considerably in water column conditions (Table 2). Dissolved oxygen in the water column ranged from 1.0 to $7.3 \mathrm{mg} \mathrm{l}^{-1}$ (average $4.3 \pm 2.2 \mathrm{sd} \mathrm{mg} \mathrm{l}^{-1}$ ). Nitrate could only be detected in FS1, FS2 and C3. FS2 had a fivefold higher nitrate concentration than FS 1 and a 15 fold higher nitrate concentration than C3. Sediment organic matter averaged $30.0 \pm 27.5$ sd\%. Ditch temperatures were on average $19.7 \pm 2.8 \mathrm{sd}^{\circ} \mathrm{C}$. SP3 had highest EC, due to high amounts of chloride-rich groundwater seepage. 


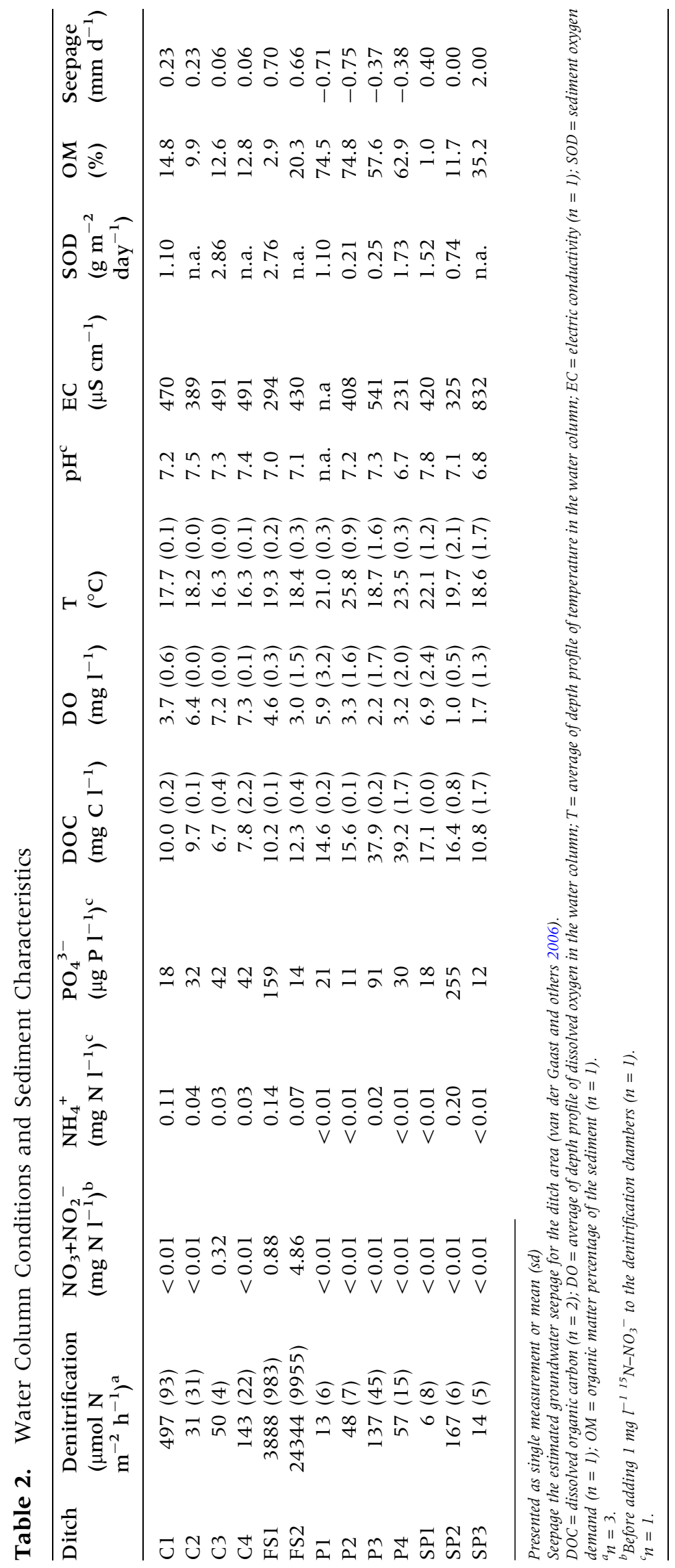



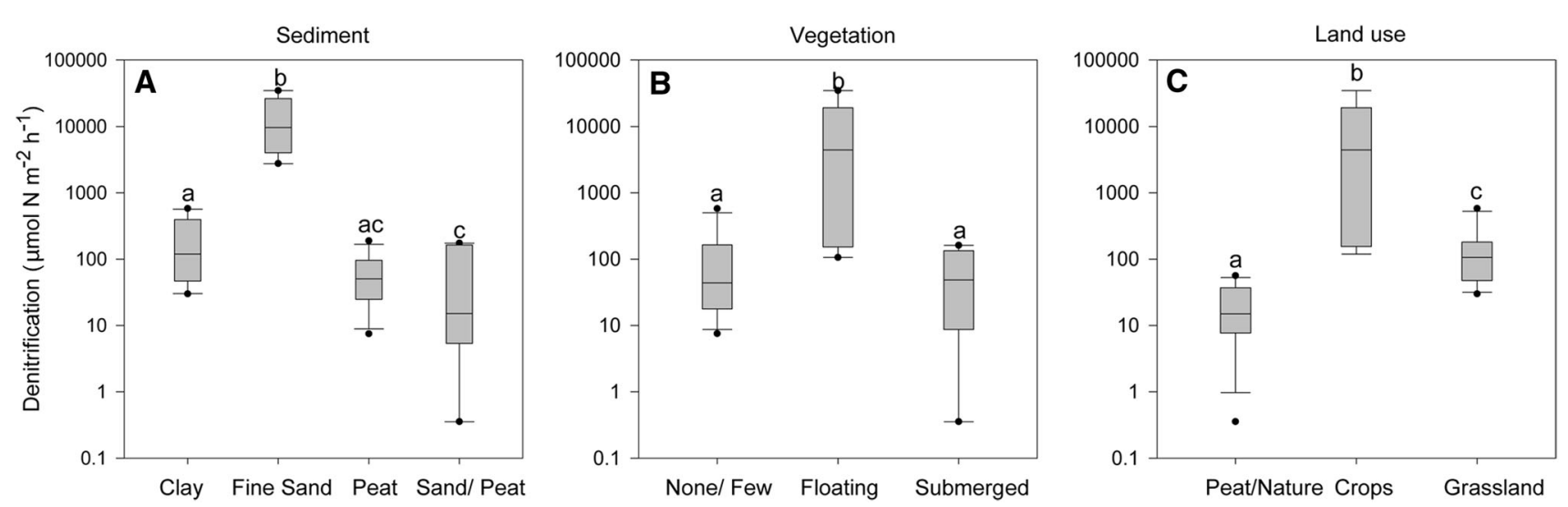

Figure 2. Denitrification rates for each of the sediment $(\mathbf{A})$ vegetation $(\mathbf{B})$ and land-use $(\mathbf{C})$ types studied. Data of all denitrification chambers sampled are plotted. Boxes indicate the 25 th-75th percentiles; lines indicate the mean; whiskers indicate 10th-90th percentiles; points indicate the 5th and 95th percentiles. Letters indicate homogeneous subsets (Tukey post hoc, $\alpha=0.05)$. *

\section{Denitrification}

Denitrification rates varied widely between the ditches, averaging $2261 \pm 6718 \mathrm{sd} \mu \mathrm{mol} \mathrm{N} \mathrm{m}{ }^{-2} \mathrm{~h}^{-}$ ${ }^{1}$ (Table 2), with considerable within ditch variability $(n=3$, Table 2$)$. Denitrification rates differed among sediment types (One-way ANOVA, $\mathrm{F}_{3}=33.683, \quad P<0.001$, Figure $\left.2 \mathrm{~A}\right)$, vegetation types (One-way ANOVA, $F_{2}=19.307, P<0.001$, Figure 2B) and land-use types (One-way ANOVA, $\mathrm{F}_{2}=35.129, P<0.001$, Figure $\left.2 \mathrm{C}\right)$. Denitrification rates were highest in the ditches with sediments consisting of fine sand (FS1 and FS2, Tukey post hoc, $P<0.01$, Figure $2 \mathrm{~A}$ ), followed by clay and peat ditches, with significantly higher rates in clay ditches than in ditches containing mixtures of sand and peat. Rates were highest in ditches covered by floating vegetation (FS1, FS2, P3; Tukey post hoc, $P<0.01$, Figure 2B), and in ditches in agricultural areas (Crops $>$ Grasslands $>$ Peatland/Nature reserves, Tukey post hoc, $P<0.01$, Figure $2 \mathrm{C}$ ). Denitrification rates significantly correlated to nitrate $\left(R^{2}=0.667, P=0.001\right.$, Figure $3 \mathrm{~A}$, Table S.2), although this correlation is heavily driven by three data points, whereas the other samples are at the detection limit. Denitrification also correlates to ammonium $\left(R^{2}=0.317, \quad P<0.05\right)$, and total nitrogen $\left(R^{2}, 0.317, \quad P<0.05\right)$, but not to organic matter content, relative abundance, and DGGE-obtained richness of denitrifier gene pools (Table S.2, Figure S.2), When excluding peat ditches, which have more refractive organic matter, there was also no relation between organic matter content and denitrification rates $\left(R^{2}=\right.$ $0.244, P=0.213)$.

\section{NirK, nirS and nosZ I Structure and Abundance}

A total number of 94 nirK, 87 nirs and 67 nos $Z_{I}$ OTUs were observed in the ditches (Table 3). Highest similarity of OTU occurrence was observed for $n o s Z_{I}$, where $57 \%$ of the DGGE-bands occurred in all ditches, whereas lowest similarity $(40 \%)$ was observed for nirs. For all genes studied, several distinct clusters of ditches with similar denitrifier communities were observed based on the presence/ absence of the different OTUs (Figure S.1). Band analysis clustered the ditches mostly in groups that related to their sediment characteristics or vegetation type: ditches with clay sediments, or fine, sandy sediments always showed distinct clusters, peat and sand/peat ditches showed more variation for nirK and nirS, but clustered according to sediment type for nos $Z_{I}$. For nirK all ditches with floating vegetation clustered together. Ditch SP3 formed the overall outgroup for nirS and nirK, with only 40 (nirS) or 50 (nirK) \% similarity with the other ditches.

Redundancy analysis clustered the ditches by sediment and vegetation type (Figure 4). For nirK, the first RDA axis was mainly explained by conditions in the sediment and explained 19\% of the variance in OTUs. The second RDA axis explained $15 \%$ of the variation and was mostly defined by concentrations of solutes, and primary production (Figure 4A), with vegetated ditches on the negative side of the axis, and most unvegetated ditches on the positive side of the axis. Variation in nirS OTUs was better explained than for nirk, the first axis explaining $26 \%$ of variation, mostly defined by 

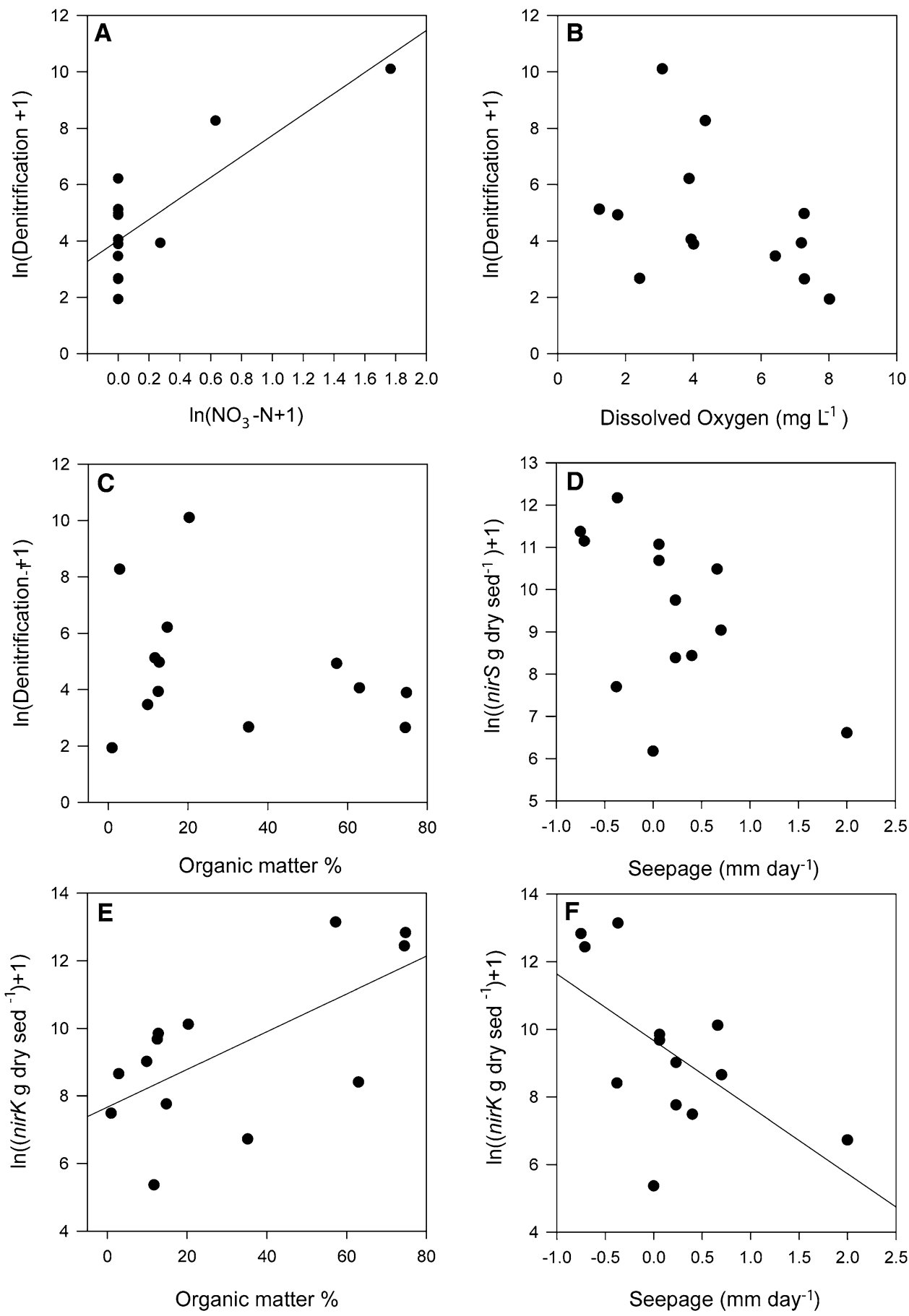

nutrient availability, the second 15\%, mostly explained by conductivity and $\mathrm{pH}$, showing the same general clustering pattern as nirK. For nos $Z_{I}$, the ditches clustered only by sediment type, regardless of vegetation, the first axis explaining $21 \%$ of the variation, the second $16 \%$.

Copy numbers of nirK, nirS and nos $Z_{I}$ per gram dry sediment were on average $9 \times 10^{4} \pm 1.7 \times 10^{5} \mathrm{sd}$, $4.1 \times 10^{4} \pm 5.4 \times 10^{4}, 74 \pm 76$, respectively. NirK,

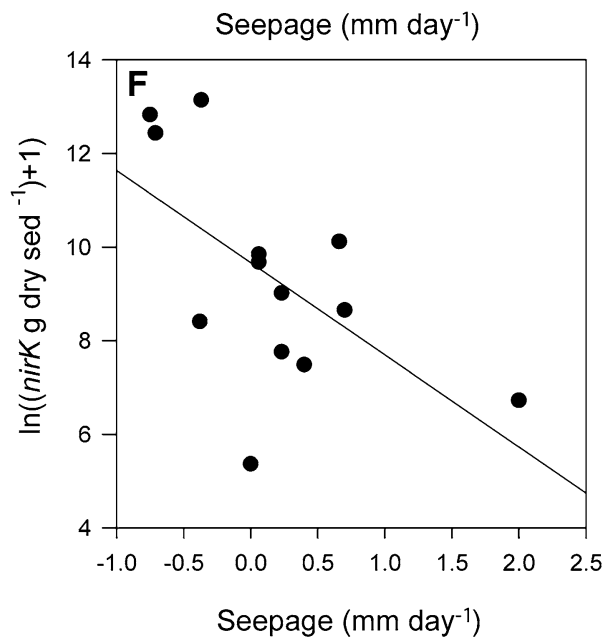

Figure 3. Relations between $\mathbf{A}$ denitrification and nitrate (linear

regression

$y=4.02+3.73 x$

$\left.R^{2}=0.667\right), \mathbf{B}$

denitrification and dissolved oxygen, $\mathbf{C}$ denitrification and organic matter \% of the sediment, D nirs gene copies per g. sediment and groundwater seepage, E nirK gene copies per g. sediment and organic matter \% of the sediment (linear regression $y=7.67+0.06 x$ $\left.R^{2}=0.421\right)$, f nirK gene copies per g. sediment and groundwater seepage (linear regression: $y=9.67-1.97 x$, $\left.R^{2}=0.367\right)$.

nirs and nos $Z_{I}$ copies per ng sample DNA were on average $1 \times 10^{2} \pm 2 \times 10^{2}, 55 \pm 78,0.1 \pm 0.1$, respectively (Table 3 ). Copy numbers of nirK were significantly correlated to organic matter percentage of the sediment $\left(\ln \left(\right.\right.$ nirK $\mathrm{g}$ dry $\left.\left.\operatorname{sed}^{-1}\right)+1\right)$ versus organic matter $\%, R^{2}=0.421, P<0.05$, Figure $2 \mathrm{E}$ ), but negatively correlated to seepage $\left(R^{2}=-0.367\right.$, $P<0.05$, Figure 2D). Copy numbers of nirs were only moderately related to seepage (ln (nirs g dry 
Table 3. Abundance and Richness of the nirK, nirs and nos $Z_{I}$ Gene pools

\begin{tabular}{|c|c|c|c|c|c|c|c|c|c|}
\hline Ditch & $\begin{array}{l}\text { \# nirK } \\
\text { OTUs }\end{array}$ & $\begin{array}{l}\# \text { nirs } \\
\text { OTUs }\end{array}$ & $\begin{array}{l}\# \operatorname{nos} Z_{\mathrm{I}} \\
\text { OTUs }\end{array}$ & $\begin{array}{l}\text { \# copies } \\
\text { nirK/ } \\
\text { g dr sed. }\end{array}$ & $\begin{array}{l}\text { \# copies } \\
\text { nirS/ } \\
\text { g dr sed. }\end{array}$ & $\begin{array}{l}\text { \# copies } \\
\text { nosZ } / \\
\text { g dr sed. }\end{array}$ & $\begin{array}{l}\text { \# copies } \\
\text { nirK/ } \\
\text { ng DNA }\end{array}$ & $\begin{array}{l}\text { \# copies } \\
\text { nirS/ } \\
\text { ng DNA }\end{array}$ & $\begin{array}{l}\text { \# copies } \\
\text { nosZ }_{\mathrm{I}} / \\
\text { ng DNA }\end{array}$ \\
\hline $\mathrm{Cl}$ & 34 & 38 & 33 & $2.30 \mathrm{E}+03$ & $4.38 \mathrm{E}+03$ & 61 & 4 & 8 & 0.11 \\
\hline $\mathrm{C} 2$ & 39 & 19 & 39 & $8.20 \mathrm{E}+03$ & $1.71 \mathrm{E}+04$ & 67 & 21 & 44 & 0.17 \\
\hline C3 & 34 & 28 & 36 & $1.60 \mathrm{E}+04$ & $4.37 \mathrm{E}+04$ & 33 & 24 & 66 & 0.05 \\
\hline $\mathrm{C} 4$ & 45 & 27 & 38 & $1.90 \mathrm{E}+04$ & $6.40 \mathrm{E}+04$ & 49 & 26 & 87 & 0.07 \\
\hline FSl & 45 & 25 & 29 & $5.70 \mathrm{E}+03$ & $8.44 \mathrm{E}+03$ & 35 & 22 & 32 & 0.13 \\
\hline FS2 & 45 & 23 & 32 & $2.50 \mathrm{E}+04$ & $3.57 \mathrm{E}+04$ & 140 & 28 & 41 & 0.16 \\
\hline $\mathrm{Pl}$ & 36 & 32 & 34 & $2.50 \mathrm{E}+05$ & $6.93 \mathrm{E}+04$ & 64 & 217 & 60 & 0.05 \\
\hline $\mathrm{P} 2$ & 40 & 33 & 41 & $3.70 \mathrm{E}+05$ & $8.69 \mathrm{E}+04$ & 184 & 199 & 46 & 0.10 \\
\hline P3 & 49 & 31 & 38 & $5.10 \mathrm{E}+05$ & $1.92 \mathrm{E}+05$ & 262 & 791 & 298 & 0.41 \\
\hline $\mathrm{P} 4$ & 31 & 23 & 38 & $4.50 \mathrm{E}+03$ & $2.20 \mathrm{E}+03$ & 54 & 8 & 4 & 0.09 \\
\hline SPl & 39 & 27 & 21 & $1.80 \mathrm{E}+03$ & $4.61 \mathrm{E}+03$ & 8 & 11 & 28 & 0.05 \\
\hline SP2 & 32 & 24 & 16 & $2.10 \mathrm{E}+02$ & $4.82 \mathrm{E}+02$ & 1 & 1 & 3 & 0.00 \\
\hline SP3 & 32 & 30 & 21 & $8.30 \mathrm{E}+02$ & $7.44 \mathrm{E}+02$ & 10 & 1 & 1 & 0.01 \\
\hline
\end{tabular}

$\left.\left.\operatorname{sed}^{-1}\right), R^{2}=0.282, P<0.1\right)$. Copy numbers of nos $Z_{I}$ only tended to be related to OM\%, $(\ln (n o s Z \mathrm{~g}$ dry $\operatorname{sed}^{-1}$ ) $R^{2}=0.238, P<0.1$, Table S.2, Figure S.2). Ditches with high copy numbers of nirK or nos $Z_{I}$ also had more detected OTUs of the respective gene $\left(R^{2}=0.318, P<0.05, R^{2}=0.766, P<0.001\right)$, but this did not apply to nirS.

\section{Discussion}

\section{Factors Affecting Drainage Ditch Denitrification at Local and Regional Scales}

Denitrification rates of the studied ditches varied widely, and differed among sediment, vegetation and land-use types. Denitrification rates in the agricultural ditches in our study were high, similar to rates previously found in agricultural streams and rivers (Garćia-Ruiz and others 1998; Pattinson and others 1998; Laursen and Seitzinger 2004; Schaller and others 2004). These are among the highest denitrification rates observed in aquatic systems (Piña-Ochoa and Álvarez-Cobelas 2006). However, as drainage ditch residence times are higher, due to low flow velocities, their overall Nremoving capacity will be higher. Moreover, denitrification rates within ditches are higher than those within the meadows from which they receive $\mathrm{N}$-rich runoff (comparing rates per $\mathrm{m}^{2} / \mathrm{h}$ ). For example, although in managed grasslands up to $25 \%$ of applied fertilizer can be lost due to denitrification, maximal rates are still orders of magnitude lower than average drainage ditch denitrification rates measured in this study (de
Klein and Van Logtestijn 1994). These differences arise from the tight aquatic-terrestrial coupling and steep biogeochemical gradients in drainage ditches, leading to favourable heterogeneous oxygen conditions for coupled nitrification-denitrification.

We considered driving factors of denitrification at local scales (within-ditch) and regional (landscape) scales. At local scales, we considered sediment and vegetation types of the ditches as well as physicalchemical properties of sediment and water column and denitrifier's presence. The regional scale is captured by considering regional $\mathrm{N}$-loads and landuse (see Figure 5 for a schematic overview of effects at multiple scales). Ditches containing fine sand (FS) had higher denitrification rates than those with clay or peat sediments. Fine-textured sediments may support higher denitrification rates, because they have a larger proportion of anoxic microsites compared to coarser sediments (Valett and others 1996; Garćia-Ruiz and others 1998; Martin and others 2001; Findlay and others 2011). Clay sediments have even smaller particle size, but may have had lower denitrification rates in this study due to their lower porosity and therefore hampered diffusion of nitrate to the denitrification zone. However, these ditches were also situated in areas with lower nitrate loads and different vegetation types, which may be an alternative explanation for their lower denitrification rates. In this study, FS ditches had significantly higher nitrate concentrations than ditches of other sediment types, which can contribute to the extreme differences in denitrification rates. Additionally-and possibly as a consequence of high nutrient loads-these ditches were covered by duckweed. Complete duckweed coverage of the 


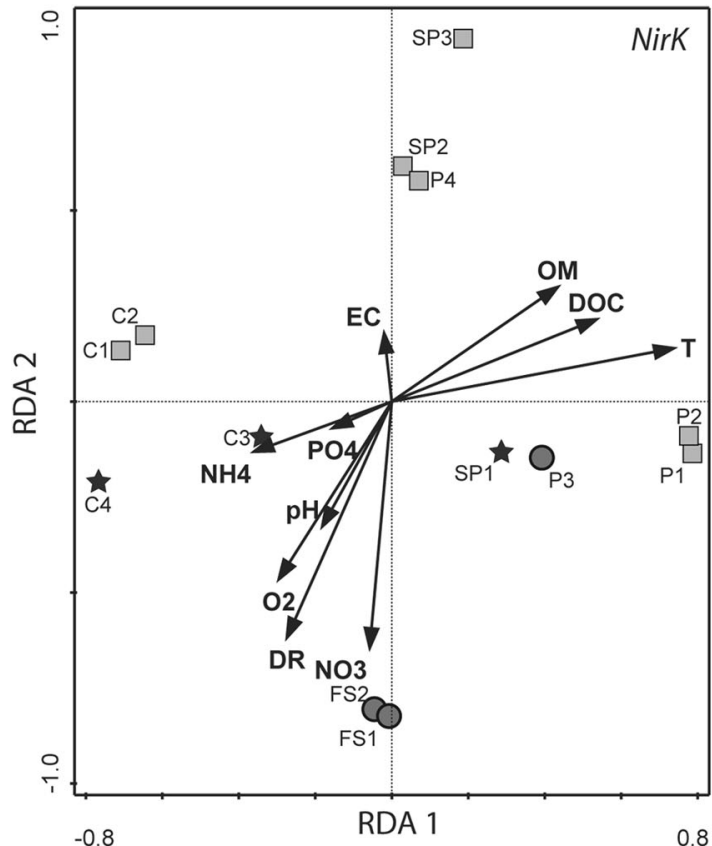

Vegetation

$\square$ none/ few

$\downarrow$ submerged

Ofloating

\section{Sediment}

$\mathrm{C}=$ clay

$\mathrm{FS}=$ fine sand

$\mathrm{P}=$ peat

$\mathrm{SP}=$ sand $/$ peat
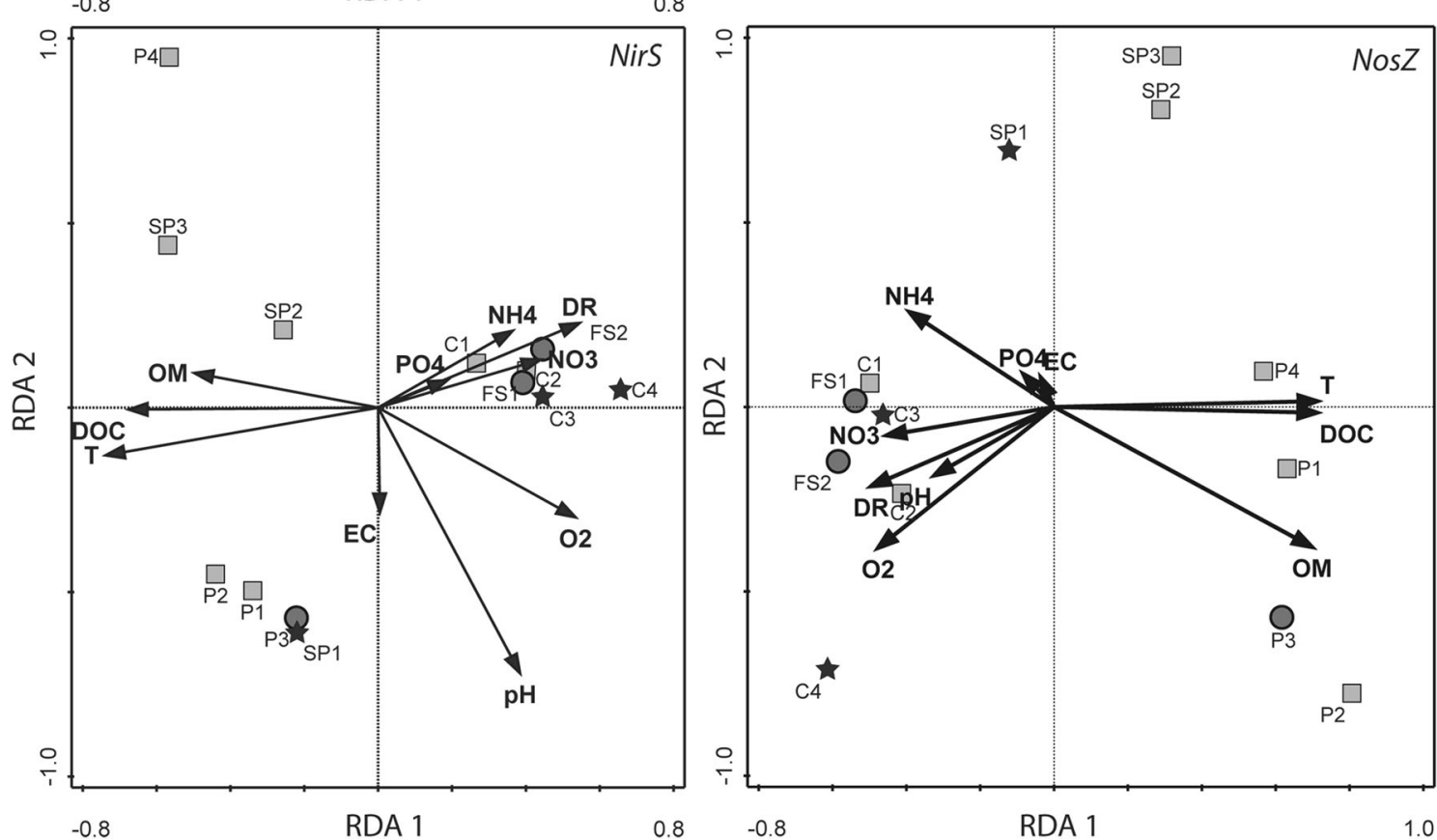

Figure 4. Redundancy analysis of nirK, nirS and nos $Z_{I}$ OTUs and environmental variables. DOC dissolved organic carbon, $D R$ denitrification rate, $E C$ electric conductivity, $O M$ organic matter content of the sediment, $T$ temperature. Units are as in Table 2. Larger distance on the plot indicates greater dissimilarity between ditches based on OTUs. Arrows indicate the direction of the largest gradient in each environmental variable. NirK Eigenvalue of axis $1(x)=0.187$; eigenvalue of axis 2 $(y)=0.149$. Significance of all canonical axes: $P<0.1$. NirS Eigenvalue of axis $1(x)=0.258$; eigenvalue of axis 2 $(y)=0.150$. Significance of all canonical axes: $P<0.05$. nos $Z_{I}$ Eigenvalue of axis $1(x)=0.207$; eigenvalue of axis 2 $(y)=0.161$. Significance of all canonical axes: $P=0.132$

water column has been shown to significantly reduce water column oxygen concentrations, and as a result, stimulate denitrification rates (Veraart and others 2011a).
Low denitrification rates were observed in the peat ditches. This may be due to nitrogen limitation, because nitrate concentrations were below detection limit in all peat ditches. Also, due to the 


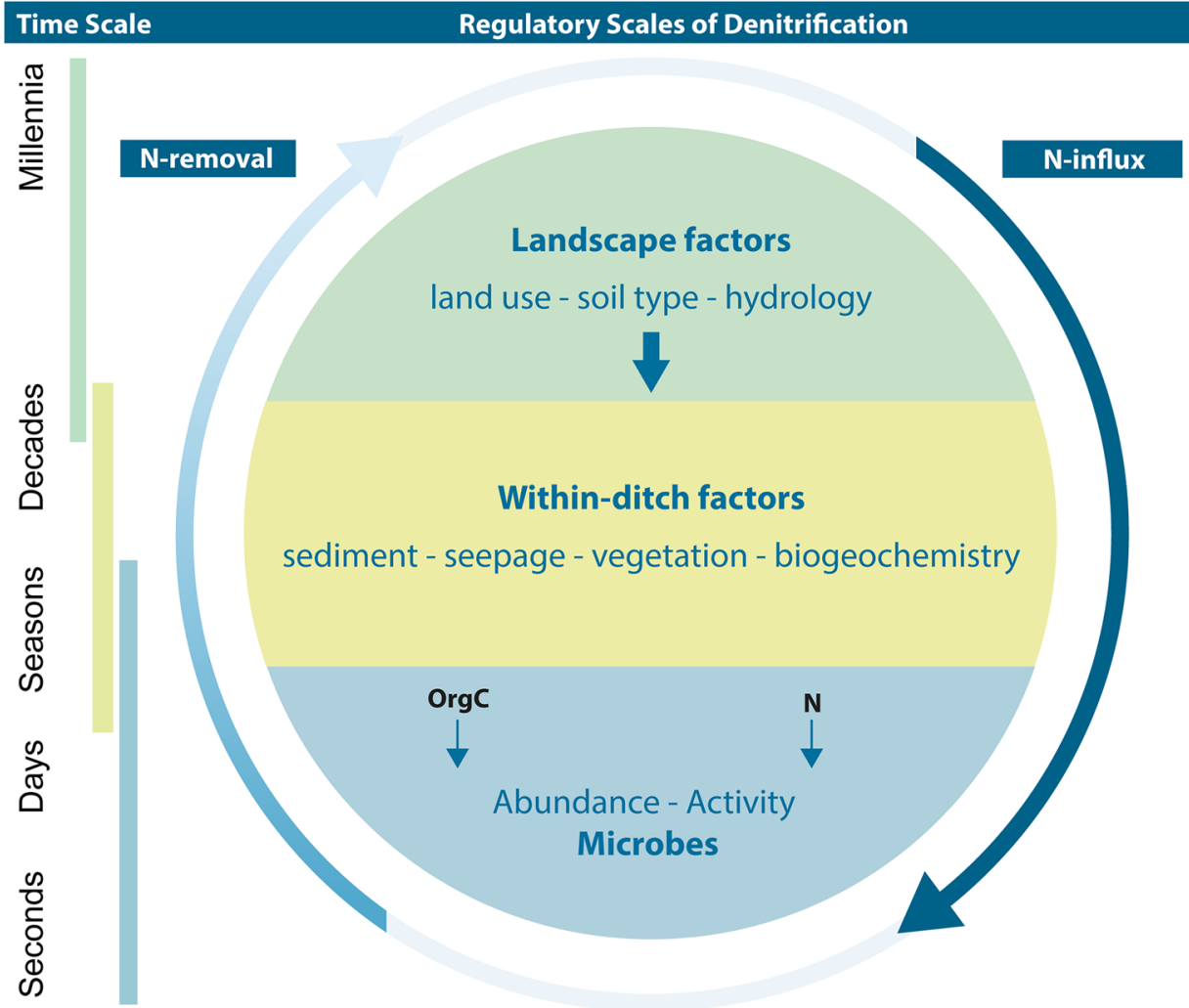

Figure 5. Schematic overview of regulation of denitrification, and its role in nitrogen removal in drainage ditches. high organic $\mathrm{C}$ to $\mathrm{NO}_{3}{ }^{-}$ratios that generally prevail in peat sediments, dissimilatory nitrate reduction to ammonium (DNRA) may have been the dominant nitrogen reducing process (Tiedje and others 1982; Burgin and Hamilton 2007). However, the organic carbon may not have been available for nitrate reducing bacteria (those performing either DNRA or denitrification) due to the presence of phenolic compounds in peat. Phenolic substances are potent enzyme inhibitors that may not only inhibit nitrate reducing enzymes directly, but also slow down microbial decomposition under anaerobic conditions (Freeman and others 2001; Freeman and others 2004), resulting in lower nitrate reduction rates due to carbon limitation.

Ditches with floating plants had higher denitrification rates than those without plants or with submerged vegetation. However, distinguishing net vegetation effects on denitrification is complex, because the type of dominant vegetation present in aquatic ecosystems largely depends on nutrient loads, sediment conditions and maintenance strategies (Janse and Van Puijenbroek 1998; Scheffer and others 2003; Kosten and others 2009; van Gerven and others 2015) which all influence denitrification as well.

Overall, denitrification rates were best explained by nitrate and ammonium concentrations, although in the case of nitrate this was mainly caused by the presence of nitrate in three ditches. The relation between nitrate and aquatic denitrification rates is well known, and arises from denitrification reaction stoichiometry (Inwood and others 2005; PiñaOchoa and Álvarez-Cobelas 2006; Mulholland and others 2008). Ammonium availability in the ditches potentially not only related to denitrification through coupled nitrification-denitrification (Eriksson and Weisner 1999), but may also reflect anoxia in the sediment, which inhibits conversion of ammonium to nitrate by nitrification.

Similar to the meta-analysis of Piña-Ochoa and Álvarez-Cobelas (2006), temperature was not a significant factor explaining denitrification rates in the ditches. This is opposed to studies of Veraart and others (201 lb) and Bachand and Horne (1999) which both found a strong temperature effect on denitrification in experimental and single-wetland setups covering a similar temperature range. This may indicate that temperature plays a role within ecosystems, but when comparing rates in different ecosystems other factors limiting denitrification, such as nitrate availability, are more important. However, all measurements for the current study were done in summer, with relatively low variability in temperatures. Over the course of a year, temperature likely has an effect. 


\section{Relative Denitrifier Richness and Abundance}

Denitrification rates in the ditches were not significantly related to DGGE-obtained nirK, nirS and $n o s Z_{I}$ richness estimates. The absence of a richnessfunction relationship in denitrifying communities may be explained by a high functional redundancy of denitrifiers (Wertz and others 2006). Also, richness estimates obtained by DGGE will not capture the true richness of denitrifiers within ditch sediments, because this method is generally assumed to visualize only those OTUs with relative abundances above $1 \%$.

Abundances of the nirK gene observed in this study were in the same range as those reported for soils (Henry and others 2004a), but contrasted observations from North American drainage ditches (Baker and others 2015), in which nirK abundances were below detection limit. Abundance of nirs was lower than reported in North American drainage ditches (Baker and others 2015), and Dutch drainage ditch slurries, rich in organic matter (Kim and others 2015), which can be explained by the different sediment characteristics of the sampled ditches. Similar to other studies, nirK and nirs genes were far more abundant than $n o s Z_{I}$ genes (Hallin and others 2009; García-Lledó and others 2011), which may point at a large proportion of denitrifiers lacking the capacity to reduce $\mathrm{N}_{2} \mathrm{O}$ to $\mathrm{N}_{2}$, and therefore a high risk of $\mathrm{N}_{2} \mathrm{O}$ emission. But, we cannot exclude that part of the nitrous oxide reducing community in the sampled ditches may belong to phylogenetic groups not covered by the primers used in this study. In freshwater sediments, abundance of sequences belonging to nos $Z$ clade II can be similar or even higher than that of sequences belonging to clade I, which were measured in this study (Jones and others 2013).

Abundances of nirK, nirs and nos $Z_{I}$ were not significantly related to denitrification rates, which is in agreement with results of Graham and others (2010) and Hallin and others (2009) for nirK and nirs but contrasts to the findings of $\mathrm{O}^{\prime}$ Connor and others(2006) for nirK, and Hallin and others (2009) for nos $Z$. The absence of such a relation may be partly caused by the fact that the presence of a denitrification gene does not mean that it is expressed-and thus functional-in the environment. Denitrifiers containing the cytochrome $c d l$ nitrate reductase enzyme NirS are expected to dominate in systems with a thick layer of well-decomposed sludge and low oxygen concentrations (Knapp and others 2009). This is in line with our findings. Copy numbers of nirs exceeded those of nirK in ditches with a layer of decomposed sludge, being the fine-sand and clay ditches in our study.

Interestingly, nirK abundance was significantly related to organic matter in the sediment, as was also found by Kandeler and others (2006), but organic matter in the sediment was not related to denitrification. Also, abundance of denitrification genes tended to decline with increasing groundwater-seepage estimates, linking to long-term effects on pore-water chemistry, but possibly also because increased seepage leads to decreased water and solute residence time, leaving less time for denitrification and development of the denitrifier community. Unlike denitrification rates, denitrifier gene abundance in the ditches was not related to nitrate concentration. These results indicate that denitrifier abundance is mainly controlled by conditions in the sediment acting at longer time-scales, such as organic matter's presence and micronutrients provided by seepage, whereas instantaneous denitrification rates are largely determined by nitrate availability (Graham 2010; Wallenstein 2006).

The absence of a strong denitrifier abundancedenitrification relationship can be explained by a combination of methodological and biological factors. Only one time point was sampled; thus, only capturing a snapshot of denitrification activity, the PCR primers used may not cover the entire diversity of denitrifiers present in the ditch, and lastly, denitrification genes present in the environment will only be expressed under the right conditions. Nitrate limitation may largely explain the absence of a strong relationship between denitrifier gene abundance and denitrification rates in the studied ditches.

\section{Denitrifier Community Structure Related to Environmental Conditions}

Community structures based on nirK, nirS and nos $Z_{I}$ genes were similar for similar sediment and vegetation types. Part of the variation in community structure was explained by environmental variables, indicating that specific conditions favour some denitrifiers more than others. For all three tested genes, about two-thirds of the total variation in OTUs remained unexplained and may be due to specific conditions in the sediment or geographical factors. Interestingly, not all ditches that were geographically close to each other clustered together in the RDA (for example, P3-P4, SP1-SP2), indicating that local environmental conditions, and in relation to this the dominant vegetation present, 
may play a more important role in structuring denitrifying communities. Another example of specific conditions creating different communities is ditch SP3, which was the overall outgroup in the DGGE clustering analysis and RDA of nirK and nirs. This ditch is situated in an area with high rates of groundwater seepage, which is rich in chloride and arsenic, very different hydrological and chemical conditions than the other ditches, which can have led to the different community structures in ditch SP3.

\section{Implications for Nitrogen Removal from Drainage Ditch Ecosystems}

When recalculating the measured denitrification rates to yearly values, the studied ditches would remove 0.7 to $2986 \mathrm{~g} \mathrm{~m}^{-2} \mathrm{y}^{-1}$, corresponding to 4 to $1710 \%$ of their average summer nitrogen loads (as calculated by the STONE model and van Gerven and others (2016) (Table 1, Table S.3)). In most drainage ditches in agricultural areas (grasslands and crops) more than half of the incoming $\mathrm{N}$ can be denitrified (Table S.3), suggesting that denitrification in ditches can indeed significantly contribute to purification of nitrogen polluted surface waters. Ditches in peat areas and nature reserves have lower denitrification efficiencies. In these systems, $\mathrm{N}$-loads may have been overestimated, as their wide buffer zones protect from high $\mathrm{N}$-influx. It is also important to note that these are estimates based on one time point, extrapolated to yearly values, and furthermore $\mathrm{NO}_{3}{ }^{-}$addition to nitratepoor ditches can lead to an overestimation of denitrification rates. More information on seasonal variation is needed to make more precise estimations. In practice there will be a seasonal mismatch between N-loads and denitrification potential. Highest loads occur in winter, when denitrification rates are low due to low temperatures. In summer, denitrification potential can be high, but nitrogen loads are lower than in winter, and incoming nitrogen is rapidly assimilated by the ditch vegetation (de Klein and Koelmans 2011). In some of the sampled ditches, the potential denitrification rate exceeds the estimated summer $\mathrm{N}$-load (Table S.3). This implies that during our measurements all the incoming nitrate is denitrified or taken up by the macrophytes, which is reflected by the absence of nitrate in the water column. The high denitrification and nitrate concentration in fine-sand ditches can be explained by their high seepage rates, supplying the denitrifying community with additional nitrate from the groundwater. Such relation between groundwater seepage rates and locally high denitrification rates was also found in agricultural streams (Veraart and others 2014).

These results shed light on the interplay of landscape factors, hydrology, and biogeochemistry in determining denitrification rates. To some extent, denitrification potential can be estimated from land-use type and vegetation status, which can help to calculate regional nitrogen budgets. Moreover, whereas sediment conditions structure the denitrifier community, local $\mathrm{N}$ availability determines instantaneous denitrification rates. Denitrification 'hotspots'-zones with locally enhanced process rates relative to their surroundings-can occur when hydrological flow paths supply 'missing' reactants to zones of potential activity (McClain and others 2003). In the case of FSI and FS2, upwelling nitrate-rich groundwater seepage likely supplied rate-limiting $\mathrm{N}$ to an already wellestablished denitrifying community, leading to excessively high denitrification rates.

\section{ConClusions}

Drainage ditches can sustain high denitrification rates, which can contribute to reducing $\mathrm{N}$-loads to adjacent surface waters. Denitrification was mainly explained by availability of nitrogen, but not significantly related to abundance of nirK, nirs or nosZ (clade I), indicators of denitrifier presence. Drainage ditches in agricultural areas, with low oxygen concentrations due to a closed cover of floating plants, and high nitrate concentrations provided by groundwater seepage, were denitrification hotspots. Our results show that denitrifier abundance is mostly controlled by long-term conditions in the sediment, whereas nitrogen availability determines instantaneous denitrification rates. Our results show how both landscape factors and within-ditch conditions affect activity and abundance of denitrifier communities, driving denitrification rates.

\section{ACKNOWLEDGEMENTS}

We thank Frits Gillissen, John Beijer and Jan van Walsem for technical assistance. We thank Hans Heilig and Phillippe Guilla Puylaert for help with DGGE and qPCR procedures, and Monique Beijaert for help with graphics. We thank Natuurmonumenten for the access to their ditches. This study was funded by the Dutch association for applied freshwater research (STOWA) and 14 Dutch water authorities as part of the PLONS-project. This is publication number 6162 of the Netherlands Institute of Ecology (NIOO-KNAW). 


\section{OPEN ACCESS}

This article is distributed under the terms of the Creative Commons Attribution 4.0 International License (http://creativecommons.org/licenses/by/ $4.0 /$ ), which permits unrestricted use, distribution, and reproduction in any medium, provided you give appropriate credit to the original author(s) and the source, provide a link to the Creative Commons license, and indicate if changes were made.

\section{REFERENCES}

Bachand PAM, Horne AJ. 1999. Denitrification in constructed free-water surface wetlands: II. Effects of vegetation and temperature. Ecol Eng 14:17-32.

Baker BH, Kröger R, Brooks JP, Smith RK, Czarnecki JMP. 2015. Investigation of denitrifying microbial communities within an agricultural drainage system fitted with low-grade weirs. Water Res 87:193-201.

Burgin AJ, Hamilton SK. 2007. Have we overemphasized the role of denitrification in aquatic ecosystems? A review of nitrate removal pathways. Front Ecol Environ 5:89-96.

de Klein JJ, Koelmans AA. 2011. Quantifying seasonal export and retention of nutrients in West European lowland rivers at catchment scale. Hydrol Process 25:2102-11.

de Klein CAM, Van Logtestijn RSP. 1994. Denitrification in the top soil of managed grasslands in The Netherlands in relation to soil type and fertilizer level. Plant and Soil 163:33-44.

Eriksson PG, Weisner SEB. 1999. An experimental study on effects of submersed macrophytes on nitrification and denitrification in ammonium-rich aquatic systems. Limnol Oceanogr 44:1993-9.

Findlay S, Mulholland P, Hamilton S, Tank J, Bernot M, Burgin A, Crenshaw C, Dodds W, Grimm N, McDowell W, Potter J, Sobota D. 2011 . Cross-stream comparison of substrate-specific denitrification potential. Biogeochemistry 104:381-92.

Freeman C, Ostle N, Kang H. 2001. An enzymic 'latch' on a global carbon store. Nature 409:149.

Freeman C, Ostle NJ, Fenner N, Kang H. 2004. A regulatory role for phenol oxidase during decomposition in peatlands. Soil Biol Biochem 36:1663-7.

García-Lledó A, Vilar-Sanz A, Trias R, Hallin S, Bañeras L. 2011. Genetic potential for $\mathrm{N}_{2} \mathrm{O}$ emissions from the sediment of a free water surface constructed wetland. Water Res 45:5621-32.

García-Ruiz R, Pattinson SN, Whitton BA. 1998. Denitrification in river sediments: relationship between process rate and properties of water and sediment. Freshwater Biol 39:467-76.

Graham DW, Trippett C, Dodds WK, O'Brien JM, Banner EBK, Head IM, Smith MS, Yang RK, Knapp CW. 2010. Correlations between in situ denitrification activity and nir-gene abundances in pristine and impacted prairie streams. Environ Pollut 158:3225-9.

Hallin S, Jones CM, Schloter M, Philippot L. 2009. Relationship between $\mathrm{N}$-cycling communities and ecosystem functioning in a 50-year-old fertilization experiment. ISME J 3:597-605.

Hallin S, Lindgren P-E. 1999. PCR Detection of Genes Encoding Nitrite Reductase in Denitrifying Bacteria. Appl Environ Microbiol 65:1652-7.

Henry S, Baudoin E, López-Gutiérrez JC, Martin-Laurent F, Brauman A, Philippot L. 2004a. Quantification of denitrifying bacteria in soils by nirK gene targeted real-time PCR. J Microbiol Method 59:327-35.

Henry S, Baudoin E, López-Gutiérrez JC, Martin-Laurent F, Brauman A, Philippot L. 2004b. Quantification of denitrifying bacteria in soils by nirK gene targeted real-time PCR. J Microbiol Methods 59:327-35.

Henry S, Bru D, Stres B, Hallet S, Philippot L. 2006. Quantitative detection of the nosZ gene, encoding nitrous oxide reductase, and comparison of the abundances of 16S rRNA, narG, nirK, and nosZ genes in soils. Appl Environ Microbiol 72:5181-9.

Herzon I, Helenius J. 2008. Agricultural drainage ditches, their biological importance and functioning. FEMS Microbiol Rev 141:1171-83.

Inwood SE, Tank JL, Bernot MJ. 2005. Patterns of denitrification associated with land use in 9 midwestern headwater streams. J N Am Benthol Soc 24:227-45.

Janse JH, Van Puijenbroek PJTM. 1998. Effects of eutrophication in drainage ditches. Environ Pollut 102:547-52.

Jones CM, Graf DR, Bru D, Philippot L, Hallin S. 2013. The unaccounted yet abundant nitrous oxide-reducing microbial community: a potential nitrous oxide sink. ISME J 7:417-26.

Kandeler E, Deiglmayr K, Tscherko D, Bru D, Philippot L. 2006. Abundance of narG, nirS, nirK, and nosZ genes of denitrifying bacteria during primary successions of a glacier foreland. Appl Environ Microbiol 72:5957-62.

Kim SY, Veraart AJ, Meima-Franke M, Bodelier PL. 2015. Combined effects of carbon, nitrogen and phosphorus on $\mathrm{CH} 4$ production and denitrification in wetland sediments. Geoderma 259:354-61.

Knapp CW, Dodds WK, Wilson KC, O’Brien JM, Graham DW. 2009. Spatial Heterogeneity of Denitrification Genes in a Highly Homogenous Urban Stream. Environ Sci Technol 43:4273-9.

Knowles R. 1982. Denitrification. Microbiol Mol Biol Rev 46:4370.

Kosten S, Kamarainen A, Jeppesen E, van Nes EH, Peeters ETHM, Mazzeo N, Sass L, Hauxwell J, Hansel-Welch N, Lauridsen TL, Sondergaard M, Bachmann RW, Lacerot G, Scheffer M. 2009. Climate-related differences in the dominance of submerged macrophytes in shallow lakes. Glob Change Biol 15:2503-17.

Kröger R, Scott JT, Czarnecki JMP. 2014. Denitrification potential of low-grade weirs and agricultural drainage ditch sediments in the Lower Mississippi Alluvial Valley. Ecolog Eng 73:168-75.

Laursen AE, Seitzinger SP. 2004. Diurnal patterns of denitrification, oxygen consumption and nitrous oxide production in rivers measured at the whole-reach scale. Freshw Biol 49:1448-58.

Martin LA, Mulholland PJ, Jackson RW, Valett HM. 2001. Denitrification potential in sediments of headwater streams in the southern appalachian mountains, USA. J N Am Benthol Soc 20:505-19.

McClain ME, Boyer EW, Dent CL, Gergel SE, Grimm NB, Groffman PM, Hart SC, Harvey JW, Johnston CA, Mayorga E, McDowell WH, Pinay G. 2003. Biogeochemical Hot Spots and Hot Moments at the Interface of Terrestrial and Aquatic Ecosystems. Ecosystems 6:301-12.

Mengis M, Gachter R, Wehrli B, Bernasconi S. 1997. Nitrogen Elimination in Two Deep Eutrophic Lakes. Limnol Oceanogr 42:1530-43.

Mulholland PJ, Helton AM, Poole GC, Hall RO, Hamilton SK, Peterson BJ, Tank JL, Ashkenas LR, Cooper LW, Dahm CN, 
Dodds WK, Findlay SEG, Gregory SV, Grimm NB, Johnson SL, McDowell WH, Meyer JL, Valett HM, Webster JR, Arango CP, Beaulieu JJ, Bernot MJ, Burgin AJ, Crenshaw CL, Johnson LT, Niederlehner BR, O'Brien JM, Potter JD, Sheibley RW, Sobota DJ, Thomas SM. 2008. Stream denitrification across biomes and its response to anthropogenic nitrate loading. Nature 452:202-5.

Muyzer G, Smalla K. 1998. Application of denaturing gradient gel electrophoresis (DGGE) and temperature gradient gel electrophoresis (TGGE) in microbial ecology. Antonie van Leeuwenhoek 73:127-41.

Needelman B, Kleinman P, Strock J. 2007. Improved management of agricultural drainage ditches for water quality protection: an overview. J Soil Water Conserv 62:171.

Nielsen LP. 1992. Denitrification in sediment determined from nitrogen isotope pairing. FEMS Microbiol Lett 86:357-62.

Nielsen LP, Glud RN. 1996. Denitrification in a coastal sediment measured in situ by the nitrogen isotope pairing technique applied to a benthic flux chamber. Mar Ecol Progr Ser 137:181-6.

O'Connor BL, Hondzo M, Dobraca D, LaPara TM, Finlay JC, Brezonik PL. 2006. Quantity-activity relationship of denitrifying bacteria and environmental scaling in streams of a forested watershed. J Geophys Res 111:G04014.

Painter D. 1999. Macroinvertebrate distributions and the conservation value of aquatic Coleoptera, Mollusca and Odonata in the ditches of traditionally managed and grazing fen at Wicken Fen, UK. J Appl Ecol 36:33-48.

Pattinson SN, García-Ruiz R, Whitton BA. 1998. Spatial and seasonal variation in denitrification in the Swale-Ouse system, a river continuum. Sci Total Environ 210-211:289-305.

Peeters ETHM, Veraart AJ, Verdonschot RCM, van Zuidam JP, de Klein JJM, Verdonschot PFM. 2014. Sloten: Ecologisch functioneren en beheer: KNNV Uitgeverij ism STOWA en Universiteit Wageningen.

Philippot L, Hallin S. 2005. Finding the missing link between diversity and activity using denitrifying bacteria as a model functional community. Curr Opin Microbiol 8:234-9.

Piña-Ochoa E, Álvarez-Cobelas M. 2006. Denitrification in aquatic environments: a cross-system analysis. Biogeochemistry 81:111-30.

Sanguinetti CJ, Dias Neto E, Simpson AJ. 1994. Rapid silver staining and recovery of PCR products separated on polyacrylamide gels. BioTechniques 17:914-21.

Schaller JL, Royer TV, David MB, Tank JL. 2004. Denitrification associated with plants and sediments in an agricultural stream. J N Am Benthol Soc 23:667-76.

Scheffer M, Szabo S, Gragnani A, van Nes EH, Rinaldi S, Kautsky N, Norberg J, Roijackers RMM, Franken RJM. 2003. Floating plant dominance as a stable state. Proc Nat Acad Sci USA 100:4040-5.

Schrier-Uijl AP, Veraart AJ, Leffelaar PA, Berendse F, Veenendaal EM. 2011. Release of $\mathrm{CO}_{2}$ and $\mathrm{CH}_{4}$ from lakes and drai- nage ditches in temperate wetlands. Biogeochemistry 102:265-79.

Seitzinger S, Harrison JA, Böhlke JK, Bouwman AF, Lowrance R, Peterson B, Tobias C, Drecht GV. 2006. Denitrification across landscapes and waterscapes: a synthesis. Ecol Appl 16:2064-90.

Steingruber SSM, Friedrich JJ, Gächter RR, Wehrli BB. 2001. Measurement of denitrification in sediments with the ${ }^{15} \mathrm{~N}$ isotope pairing technique. Appl Environ Microbiol 67:3771-8.

Steur GGL, de Vries F, van Wallenburg C. 1985. Bodemkaart van Nederland. Wageningen: Stichting voor Bodemkartering.

Throbäck IN. 2006. Exploring denitrifying communities in the environment. Uppsala: Department of microbiology, Swedish University of Agricultural Sciences, Faculty of natural resources and agricultural sciences.

Tiedje JM, Sexstone AJ, Myrold DD, Robinson JA. 1982. Denitrification: ecological niches, competition and survival. Antonie van Leeuwenhoek 48:569-83.

Valett HM, Morrice JA, Dahm CN, Campana ME. 1996. Parent lithology, surface-groundwater exchange, and nitrate retention in headwater streams. Limnol Oceanogr 41:333-45.

van der Gaast JWJ, Massop HTL, Vroon HRJ, Staritsky IG. 2006. Hydrologie op basis van karteerbare kenmerken (in Dutch). Wageningen: Wageningen UR Alterra. p pll1.

van Gerven LP, de Klein JJM, Gerla DJ, Kooi BW, Kuiper JJ, Mooij WM. 2015. Competition for Light and Nutrients in Layered Communities of Aquatic Plants. Am Nat 186:72-83.

Veraart AJ, Audet J, Dimitrov MR, Hoffmann CC, Gillissen F, de Klein JJM. 2014. Denitrification in restored and unrestored Danish streams. Ecol Eng 66:129-40.

Veraart AJ, de Bruijne WJJ, de Klein JJM, Peeters ETHM, Scheffer M. 2011 a. Effects of aquatic vegetation type on denitrification. Biogeochemistry 104:267-74.

Veraart AJ, de Klein JJM, Scheffer M. 2011b. Warming Can Boost Denitrification Disproportionately Due to Altered Oxygen Dynamics. PLoS One 6:e18508.

Wallenstein MD, Myrold DD, Firestone M, Voytek M. 2006. Environmental controls on denitrifying communities and denitrification rates: insights from molecular methods. Ecol Appl 16:2143-52.

Wertz S, Degrange V, Prosser JI, Poly F, Commeaux C, Freitag T, Guillaumaud N, Roux XL. 2006. Maintenance of soil functioning following erosion of microbial diversity. Environ Microbiol 8:2162-9.

Wolf J, Beusen AHW, Groenendijk P, Kroon T, Rötter R, van Zeijts H. 2003. The integrated modeling system STONE for calculating nutrient emissions from agriculture in the Netherlands. Environ Model Softw 18:597-617.

Zhang S, Liu F, Xiao R, Li Y, He Y, Wu J. 2016. Effects of vegetation on ammonium removal and nitrous oxide emissions from pilot-scale drainage ditches. Aquat Bot 130:37-44. 